\title{
柔層と岡層が混在する多層建築物の地震応答特性とその評価 \\ EARTHQUAKE RESPONSE CHARACTERISTICS AND ITS EVALUATION FOR MULTI-STORY BUILDINGS CONSISTING OF MIXED SOFT AND RIGID STORIES
}

\author{
秋田知 芳*, 倉本 洋** \\ Tomofusa AKITA and Hiroshi KURAMOTO
}

\begin{abstract}
Equations for evaluating the time history responses of the story shear and story drift of multi-story regular-shaped buildings had been proposed by one of the authors. The applicability of the proposed equations to multi-story irregular-shaped buildings consisting of mixed soft and rigid stories in which the story collapse mechanism is formed under earthquake motions was investigated in this study. This paper shows that the equation for the story shear response is applicable to the irregular-shaped buildings. On the other hand, the prediction accuracy of the story drift response by the proposed equation for the irregular-shaped buildings is less than that for the regular-shaped buildings, because the variation of higher vibration modes in the irregular-shaped buildings is larger than that in the regular-shaped buildings. Then, an equation for evaluating the time history responses of the story drift considering the effect of the variation of higher vibration modes is proposed.
\end{abstract}

Keywords: Buildings with story collapse mechanism, Evaluation of time history response, Higher mode response, Equivalent mass ratio, Variation of higher vibration modes 層崩壊型建筑物、時刻歴応答評価、高次モード応答、等価質量比、高次モード変動

1.はじめに

限界耐力計算 ${ }^{1)}$ では等価線形化法 ${ }^{2}$ に基づく応答スペクトル法に よって地震応答を評価する手法が採用されている。したがって、応 答値評価の際には、多自由度系で構成される建築物を必然的に等価 1 自由度系に縮約することとなる。しかしながら、等価 1 自由度系 による応答值評価では高次モード応答が無視されるため、その影響 を如何に考慮するかが限界耐力計算の応答予測精度を向上させるた めの検討課題のひとつとなっている ${ }^{3)}$ 。

筆者らはこの問題の解決を目的として、多層純フレーム建築物 4),5)、 多層制震建築物 ${ }^{6)}$ および多層壁フレーム建築物 7)を対象に地震応答 評価において高次モードの影響を考慮する方法を提案し、その妥当 性を検証してきた。しかし、これまでに対象としてきた建築物は概 ね立面的に整形であり、ピロティ建築物や中間層に柔弱層を有する 建築物等の不整形な建築物（以下、層崩壊型建築物之呼称）に対す る検討は行っていない。

このような層崩壊型建築物の地震応答評価に関して、岡野ら ${ }^{8)}$ は 層降伏機構を形成する 6 層鉄筋コンクリート造建築物を対象とした 検討から高次モードの影響により 1 次モードの性状が変化すること を指摘し、モード間相互の影響を考慮した地震応答評価法 (NoLMM 解析）を提案している。また、小林ら ${ }^{97}$ は中間層免震構造に関して、 免震層上部構造の応答増幅が免震層下部構造と上部構造の振動モ一 ド間の連成作用に起因していることを示し、これを考慮した中間層 免震構造の応答分布予測式を提案している。同じく山下ら ${ }^{10)}$ は中間 層免震構造において、免震層の挿入位置が高いほど免震層より下層
部のせん断応力が大きくなる傾向があることや、免震層上部におい て高次モードの影響を大きく受けるようになることを指摘している。 しかしながら、これらの層崩壊型建築物に関する研究は、高次モ ード応答を含めた応答層せん断力 (応答加速度)、応答層間変形の最 大值の評価を試みているものであり、高次モード応答を含めた地震 応答全体、すなわち時刻歴地震忘答そのものの評価に着目したもの ではない。

一方、高次モード応答を含めた時刻歴地震応答を評価することが できれば最大応答值をはじめ、高次モード応答を含めた層崩壊型建 築物の地震応答性状をより詳細に把握することが可能となる。筆者 らは既報 ${ }^{4)}$ において立面的に整形な多層建築物の層せん断力および 層間変形の時刻歴 $Q_{i}(t)$ および ${ }_{s t} \delta_{i}(t)$ が式(1)および(2)による略算式 で精度良く評価できることを示した。

$$
\begin{aligned}
& Q_{i}(t)=\sum_{j=i}^{N} m_{j}\left\{\sum_{s=1}^{2}{ }_{s} \beta \cdot{ }_{s} u_{j} \cdot S_{s}(t)-\left(1-\sum_{s=1}^{2} \beta_{s} s_{s} u_{j}\right) \cdot \ddot{x}_{\theta}(t)\right\} \\
& { }_{s t} \delta_{i}(t)={ }_{l} \beta\left({ }_{1} u_{i}-, u_{i-1}\right), \Delta(t) \\
& +{ }_{h} \beta\left({ }_{h} u_{i}-{ }_{h} u_{i-1}\right) \frac{\sum_{s=2}^{3}{ }_{s} \bar{M} \cdot{ }_{s} \Delta(t)+{ }_{l} \bar{M}_{e} \cdot \Delta_{e}(t){ }_{l} \bar{M} \cdot{ }_{l} \Delta(t)}{{ }_{2} \bar{M}+{ }_{i} \bar{M}_{e}-{ }_{l} \bar{M}} \\
& \text { ただし、 }{ }_{1} u_{0}={ }_{h} u_{0}=0 \\
& { }_{h} \beta \cdot{ }_{h} u_{i}={ }_{2} \beta \cdot{ }_{2} u_{i}+{ }_{l} \beta \cdot{ }_{e} \cdot u_{e i}-{ }_{l} \beta \cdot{ }_{l} u_{i} \\
& \text { ここに、 } m_{i}: i \text { 層の質量 } \\
& { }_{1} \bar{M} \text { : 等価 } 1 \text { 次モードに対する等価質量 } \\
& { }_{i} \bar{M}_{e} \text { : 弾性 } 1 \text { 次モードに対する等価質量 }
\end{aligned}
$$

Graduate Student, Toyohashi University of Technology, M. Eng. Assoc. Prof., Department of Architecture \& Civil Engineering, Toyohashi University of Technology, Dr. Eng.
* 豊橋技術科学大学大学院丁学研究科 大学院生・修十(工学

** 豊橋技術科学大学工学部建設-[学系 准教授・博士(工学) 
${ }_{2} \bar{M}$ ：弹性 2 次モードに対する等価質量 ${ }_{3} \bar{M}$ : 弾性 3 次モードに対する等価質量 ${ }_{s} S_{a}(t)$ : 時刻 $t$ における $s$ 次の応答加速度 $\ddot{x}_{0}(t)$ : 時刻 $t$ における地動の加速度 ${ }_{1} \beta \cdot u_{i}: i$ 層における等価 1 次の刺激関数 ${ }_{1} \beta_{e l} u_{e i}: i$ 層における弹性 1 次の刺激関数 ${ }_{2} \beta{ }_{2} u_{i}: i$ 層における弾性 2 次の刺激関数 ${ }_{1} \Delta(t)$ : 時刻 $t$ における等価 1 次の代表変位 ${ }_{1} \Delta_{e}(t)$ : 時刻 $t$ における弾性 1 次の代表変位 ${ }_{2} \Delta(t)$ : 時刻 $t$ にお污る弾性 2 次の代表変位 ${ }_{3} \Delta(t)$ : 時刻 $t$ における弾性 3 次の代表变位

本研究は、層崩壊型建築物のような柔層と剛層が混在する多層建 築物に対する限界耐力計算による地震応答評価に、高次モードの影 響を取り入れることを目的としたものである。本論では、柔弱層の 位置が異なる 4 棟の層崩壊型建築物および壁フレームタイプの層 崩壊型建築物 1 棟を対象として、純フレーム建築物に対して提案し た式(1)および(2)を用いて層せん断力および層間変形の時刻歴応答 を評価し、その適用性および適用範囲について検郡する。また、地 震応答特性の検討を行い、その検討結果に基づいてより適切な層崩 壊型建築物の層せん断力および層間変形の時刻歷応答の評価式を 提案し、その妥当性を検証する。

\section{2. 解析対象建築物および解析概要}

解析対象とした建築物は、図 1 (a) (d)に示す桁行方向が $7.2 \mathrm{~m} \times 6$ スパン、張間方向が $10.8 \mathrm{~m} \times 1$ スパンの 14 層ピロティ建築物 （14F01）およびそれぞれ 3 層、 7 層および 12 層が独立柱で他層が 連層耐震壁で構成される中間柔弱層建築物（14F03、14F07 および 14F12）と、図 1 (e)に示す文献 4)で対象とした桁行方向および張間 方向ともに $6.0 \mathrm{~m} \times 3$ スパンの 12 層純フレーム建築物の 6 層以外の 中央構面全てに耐震壁を配置した壁フレームタイプの中間柔弱層 建築物（12F06）の計 5 種類である。14 層モデルの耐震壁および独 立柱の断面詳細を表 1 および 2 に示す。14F01、14F03、14F07およ

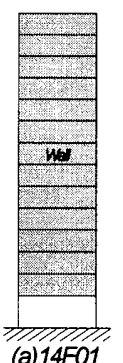

(a) 14F01

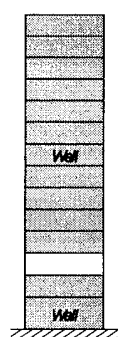

$\begin{array}{lll}\text { (b) } 14 F 03 & \text { (c) } 14 F 07\end{array}$ Elevation

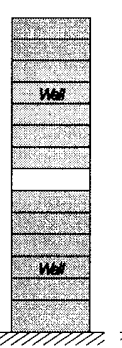

n

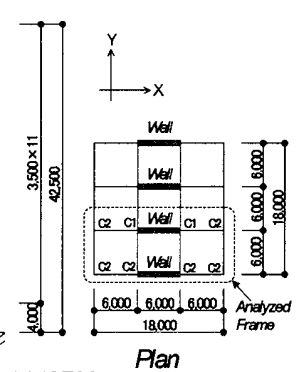

(e) $12 F 06$
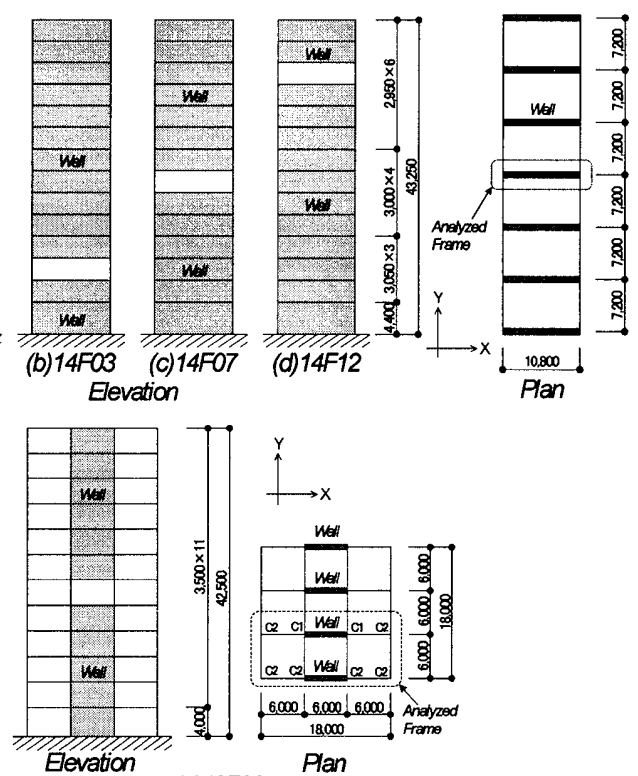

図 1 解析対象建築物
び 14F12 は、それぞれ 1 層、3 層、7層および 12 層において表 1 に 示す側柱付耐震壁を表 2 に示す独立柱に置き換えたものである。ま た、表 3〜 5には 12F06 の柱、耐震壁および梁の断面詳細を示して いる。なお、本論では各解析モデルにおいて独立柱のみで構成され る層を柔層とし、耐震壁が配置された層を剖層と定義している。

解析は 14 層モデルでは張間方向の中間部 1 構面を、12 層モデル では片側 2 構面を取り出して行い、それぞれに対して平面フレーム モデルによるモード適応型静的非線形荷重増分解析 ${ }^{11}$ ) (以下、MAP 解析と呼称）と時刻歷地震応答解析を実施した。なお、MAP 解析と は建築物の塑性化に伴うモード形の変化を考虑した弾塑性 1 次モー ド比例の外力分布を用いて荷重增分解析を行うものである。

表 114 層モデルの側柱および耐震壁の断面詳細

\begin{tabular}{|c|c|c|c|c|c|c|c|}
\hline \multirow{3}{*}{ 階 } & \multirow{3}{*}{$\begin{array}{c}F c \\
\left(\mathrm{~N} / \mathrm{mm}^{2}\right)\end{array}$} & \multicolumn{4}{|c|}{ 挂 } & \multirow{2}{*}{\multicolumn{2}{|c|}{ 酎憵壁 }} \\
\hline & & \multirow{2}{*}{ 断面 } & \multicolumn{2}{|r|}{ 主筋 } & \multirow{2}{*}{ 带筋 } & & \\
\hline & & & x方向 & Y方向 & & 壁厚 & 壁笳 \\
\hline $9 \mathrm{~F}-14 \mathrm{~F}$ & 27 & $900 \times 1050$ & 5-D29 & 2-D29. 3-D16 & $8-D 10 @ 200$ & 150 & D10@150Single \\
\hline $6 F-8 F$ & 27 & $1000 \times 1050$ & $7-029$ & 2-D29, 3-D16 & 6-D13@200 & 180 & D10@200Double \\
\hline $5 \mathrm{~F}$ & 30 & $1000 \times 1050$ & $7-D 29$ & 2-D29, 3-D16 & 6-D13@200 & 180 & D10@200Double \\
\hline $3 \mathrm{~F}, 4 \mathrm{~F}$ & 30 & $1050 \times 1050$ & $10-\mathrm{D} 29$ & 2-D29, 3-D19 & 8-D13@200 & 200 & D10@150Double \\
\hline $1 F, 2 F$ & 33 & $1050 \times 1050$ & $10-\mathrm{D} 29$ & 2-D29, 3-D19 & $8-D 13 @ 200$ & 200 & D10@150Double \\
\hline
\end{tabular}

主霄:SD390, 带露:SD345, 壁落:SD345

\section{表 2 独立柱の断面詳細}

\begin{tabular}{|c|c|c|c|c|c|c|}
\hline \multirow{3}{*}{ モデル } & \multirow{3}{*}{ 階 } & \multirow{3}{*}{$\begin{array}{c}\mathrm{Fc} \\
\left(\mathrm{N} / \mathrm{mm}^{2}\right)\end{array}$} & \multicolumn{4}{|c|}{ 柱 } \\
\hline & & & \multirow{2}{*}{ 断面 } & \multicolumn{2}{|r|}{ 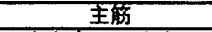 } & \multirow{2}{*}{ 带筋 } \\
\hline & & & & $x$ 方向 & Y方向 & \\
\hline $14 \mathrm{~F} 12$ & $12 \mathrm{~F}$ & 27 & $800 \times 800$ & 5-D29 & 2-D29, 3-D19 & 6-D10@200 \\
\hline $14 \mathrm{~F} 07$ & $7 F$ & 27 & $1000 \times 1050$ & 7-D29 & 2-D29, 3-D19 & $8-D 10 @ 200$ \\
\hline $14 \mathrm{FO3}$ & $3 \mathrm{~F}$ & 30 & $1050 \times 1050$ & 7-D29 & 2-D29, 3-D19 & 9-D10@100 \\
\hline $14 \mathrm{~F} 01$ & $1 \mathrm{~F}$ & 33 & $1200 \times 1200$ & $10-\mathrm{D} 29$ & 9-D29 & 12-D10@100 \\
\hline
\end{tabular}

表 3 柱断面詳細 (12F06)

\begin{tabular}{|c|c|c|c|c|c|c|c|}
\hline \multirow{2}{*}{ 跸 } & \multirow{2}{*}{ 符昂 } & \multirow{2}{*}{$\begin{array}{c}F c \\
\left(\mathrm{~N} / \mathrm{mm}^{2}\right)\end{array}$} & \multirow{2}{*}{ 断面 } & \multicolumn{3}{|c|}{ 主萠 } & \multirow{2}{*}{ 带筋 } \\
\hline & & & & X方向 & Y方向 & 芯筋 & \\
\hline \multirow{2}{*}{$9 F-12 F$} & $\mathrm{C} 1$ & 24 & $850 \times 850$ & 5-D29 & 5-D29 & 0 & 2-D13@100 \\
\hline & $\overline{\mathrm{C} 2}$ & 24 & $850 \times 850$ & $5-D 29$ & $5-\mathrm{D} 29$ & 0 & 2-D13@100 \\
\hline \multirow{2}{*}{$5 F-8 F$} & C1 & 30 & $850 \times 850$ & $5-\mathrm{D} 32$ & 5-D32 & 0 & 2-D13@100 \\
\hline & $\mathrm{C2}$ & 30 & $850 \times 850$ & $5-D 32$ & 5-D32 & 0 & 2-D13@100 \\
\hline \multirow{2}{*}{$2 F-4 F$} & C1 & 36 & $850 \times 850$ & $6-D 35$ & 6-D35 & 0 & 3-D13@100 \\
\hline & $\mathrm{C2}$ & 36 & $850 \times 850$ & 5-D35 & 5-D35 & $8-\mathrm{D} 35$ & $3-D 13 @ 100$ \\
\hline \multirow{2}{*}{$1 \mathrm{~F}$} & C1 & 36 & $850 \times 850$ & 6-D35 & 6-D35 & 0 & 3-D13@100 \\
\hline & C2 & 36 & $850 \times 850$ & 6-D35 & $6-D 35$ & $8-D 35$ & 3-D13@100 \\
\hline
\end{tabular}

\begin{tabular}{|c|c|c|c|}
\hline 踷 & $\begin{array}{c}\mathrm{Fc} \\
\left(\mathrm{N} / \mathrm{mm}^{2}\right)\end{array}$ & 壁厚 & 壁笳 \\
\hline $9 \mathrm{~F}-12 \mathrm{~F}$ & 24 & 300 & \begin{tabular}{|l} 
D13@200Double \\
\end{tabular} \\
\hline $5 F, 7 F, 8 F$ & 30 & 300 & D13@200Double \\
\hline $1 F-4 F$ & 36 & 300 & D13@200Double \\
\hline
\end{tabular}

表 5 梁断面詳細 (12F06)

\begin{tabular}{|c|c|c|c|c|c|c|}
\hline \multirow{2}{*}{ 階 } & \multirow{2}{*}{$\begin{array}{c}\mathrm{Fc} \\
\left(\mathrm{N} / \mathrm{mm}^{2}\right)\end{array}$} & \multirow{2}{*}{ 断面 } & \multicolumn{3}{|c|}{ 王能 } & \multirow{2}{*}{ あばら筋 } \\
\hline & & & & 1段筋 & 2段筋 & \\
\hline \multirow{2}{*}{ RF } & \multirow[t]{2}{*}{24} & \multirow{2}{*}{$00 \times 800$} & 上 & 4-D25 & $1-025$ & \multirow{2}{*}{ 3-D13@150 } \\
\hline & & & 下 & 4-D25 & - & \\
\hline \multirow{2}{*}{$12 \mathrm{~F}$} & \multirow{2}{*}{24} & \multirow{2}{*}{$500 \times 800$} & 上 & 4-D25 & 2-D25 & \multirow{2}{*}{ 3-D13@150 } \\
\hline & & & $\bar{T}$ & 4-D25 & - & \\
\hline \multirow{2}{*}{$11 \mathrm{~F}$} & \multirow[t]{2}{*}{24} & \multirow{2}{*}{$500 \times 800$} & 上 & 4-D29 & $1-\mathrm{D} 29$ & \multirow{2}{*}{ 4-D13@150 } \\
\hline & & & $\bar{T}$ & 4-D29 & $1-\mathrm{D} 29$ & \\
\hline \multirow{2}{*}{$10 \mathrm{~F}$} & \multirow{2}{*}{24} & \multirow{2}{*}{$500 \times 800$} & 上 & 4-D29 & 2-D29 & \multirow{2}{*}{ 4-D13@150 } \\
\hline & & & $\bar{T}$ & 4-D29 & $1-\mathrm{D} 29$ & \\
\hline \multirow{2}{*}{$8 \mathrm{~F} .9 \mathrm{~F}$} & \multirow[t]{2}{*}{20} & \multirow{2}{*}{$500 \times 800$} & 上 & 4-D29 & 3-D29 & \multirow{2}{*}{ 4-D13@150 } \\
\hline & & & 下 & $4-D 29$ & $2-D 29$ & \\
\hline \multirow{2}{*}{$6 F, 7 F$} & \multirow{2}{*}{30} & \multirow{2}{*}{$500 \times 800$} & 上 & 4-D32 & 4-D32 & \multirow{2}{*}{$4-D 13 @ 150$} \\
\hline & & & $\bar{T}$ & $4-D 32$ & 2-D32 & \\
\hline \multirow[t]{2}{*}{$5 \mathrm{~F}$} & \multirow[t]{2}{*}{36} & \multirow{2}{*}{$500 \times 800$} & 上 & 4-D32 & 4-D32 & \multirow{2}{*}{ 4-D13@150 } \\
\hline & & & 下 & 4-D32 & 2-D32 & \\
\hline \multirow{2}{*}{$2 F-4 F$} & \multirow{2}{*}{36} & \multirow{2}{*}{$500 \times 800$} & 上 & 4-D35 & 4-D35 & \\
\hline & & & $\bar{T}$ & 4-D35 & 3-D35 & \\
\hline $1 \mathrm{~F}$ & 36 & $500 \times 3000$ & 上 & 8-D29 & 4-D29 & \\
\hline & & & & $8-D 29$ & & 4-D16@200 \\
\hline
\end{tabular}



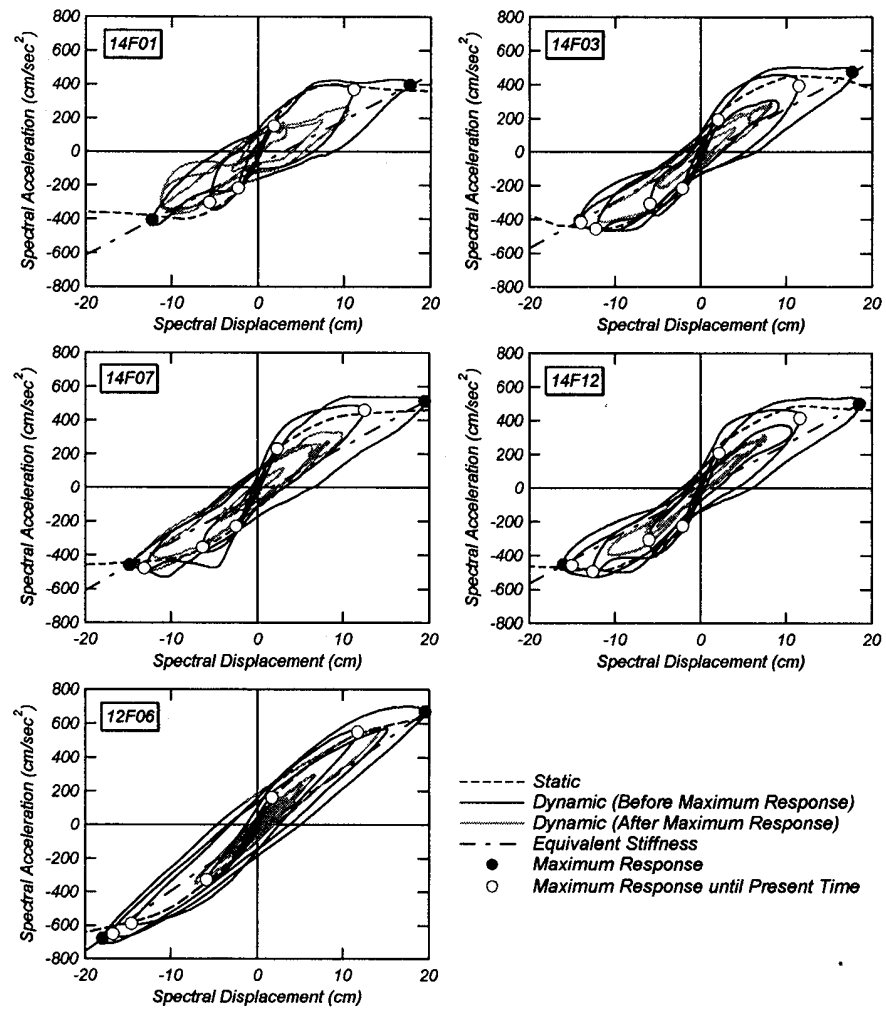

図 2 等価 1 自由度系応答の比較
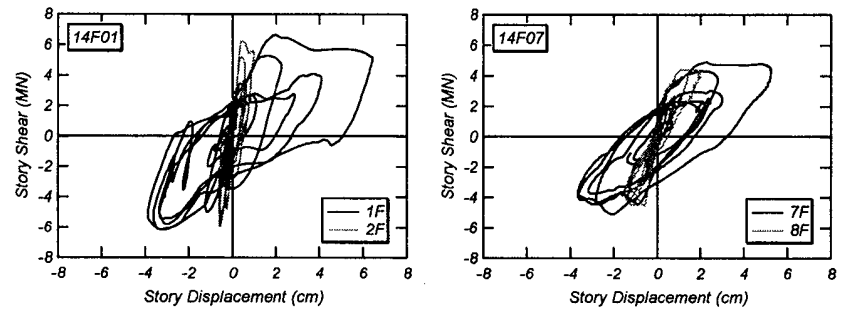

図 3 柔弱層とその他の層の層せん断カー層間変形関係の比較

解析変数には柔弱層の位置と地震波入力レベルを選択した。時刻 歴地震応答解析は、入力地震波として El Centro NS（1940）のみを用 い、最大速度をそれぞれ $25 \mathrm{~cm} / \mathrm{sec、} 50 \mathrm{~cm} / \mathrm{sec} 、 75 \mathrm{~cm} / \mathrm{sec}$ に基準化し たものを各モデルに対して入力した 15 ケースと、最大速度を $100 \mathrm{~cm} / \mathrm{sec}$ に基準化したものを 14F07 のみに入力した 1 ケースの計 16 ケースとした。梁には復元力特性を Takeda モデルとした材端バネ モデルを、柱および耐震壁にはマルチスプリングモデル ${ }^{12)}$ (MS モ デル）をそれぞれ用いた。なお、柱および而震壁ともに部材中央部 にはせん断バネを配し、せん断ひび割れによる剛性低下を考慮した が、せん断降伏は考虑していない。解析における粘性減哀は瞬間剛 性比例型とし、弾性 1 次固有周期に対して堿衰定数を $5 \%$ とした。 また、数值解析には Newmark- $\beta$ 法（ $\beta=1 / 4 ）$ を用い、解析時間は 15 秒とした。積分時間刻みは 14 層モデルでは 0.0001 秒とし、12 層モ デルでは 0.004 秒とした。

\section{3. 等価 1 自由度系応答特性}

図 2 に各モデルに対する等価 1 自由度系の縮約結果を示す。図中 の破線は MAP 解析結果による静的縮約結果であり、代表荷重一代表 変位関係 $\left({ }_{1} S_{a}-{ }_{1} S_{d}\right.$ 関係）は式(3)および(4)によって算定した ${ }^{4), 13) 。}$

$$
\begin{aligned}
& { }_{I} S_{a}=\frac{\sum_{i=l}^{N} m_{i} \cdot l}{\left(\sum_{i=1}^{N} m_{i} \cdot \delta_{i} \delta_{i}\right)^{2}} \cdot Q_{B} \quad\left(=\frac{\sum_{i=I}^{N}{ }_{I} P_{i \cdot 1} \delta_{i}}{\sum_{i=1}^{N} m_{i \cdot l} \delta_{i}}\right)
\end{aligned}
$$

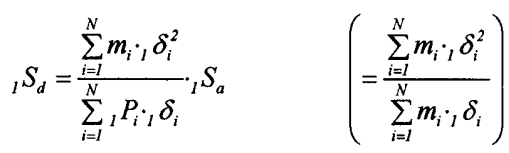

$$
\begin{aligned}
& \text { ここに、 }{ }_{1} \delta_{i} ： i \text { 層での } 1 \text { 層床位置に対する相対変位 } \\
& { }_{i} P_{i}: i \text { 層の作用水平力 } \\
& { }_{1} Q_{B}: \text { ベースシア }
\end{aligned}
$$

一方、図中の黒実線および灰色線は El Centro 波 $(75 \mathrm{~cm} / \mathrm{sec})$ 入力 時の時刻歷地震応答解析結果による動的縮約結果であり、代表荷重 一代表変形関係 $\left({ }_{I} S_{a}(t)-{ }_{I} S_{d}(t)\right.$ 関係) は式(5)および(6)によって算 定した ${ }^{4)}$ 。黒実線は最大応答以前の履歴を、灰色線は最大応答以降 の履歷をそれぞれ表している。

$$
\begin{aligned}
& { }_{l} S_{a}(t)=\frac{\sum_{i=1}^{N} P_{i}(t){ }_{1} \delta_{i}(t)}{\sum_{i=1}^{N} m_{i} \cdot \delta_{i}(t)} \\
& { }_{1} S_{d}(t)=\frac{\sum_{i=1}^{N} m_{i} \cdot{ }_{1} \beta \cdot{ }_{1} u_{i} \cdot \delta_{i}(t)}{\sum_{i=1}^{N} m_{i} \cdot{ }_{1} \beta \cdot{ }_{1} u_{i}} \quad(=, \Delta(t)) \\
& \text { ここに、 } P_{i}(t): \text { 時刻 } t \text { における } i \text { 層の作用水平力 } \\
& \delta_{i}(t) \text { : 時刻 } t \text { における } i \text { 層での } 1 \text { 層床位置に対する相対 } \\
& { }_{1} \delta_{i}(t): \delta_{i}(t) \text { の1次モード成分 }\left({ }_{1} \delta_{i}(t)={ }_{1} \beta \cdot{ }_{1} u_{i} \cdot{ }_{1} S_{d}(t)\right)
\end{aligned}
$$

なお、 1 次刺激関数, $\beta \cdot{ }_{1} u_{i}$ は式(5)および(6)により縮約した等価 1 自由度系の最大応答变位に相当する MAP 解析結果の荷重ステップ を求め、そのステップにおける各層の 1 層床位置に対する相対变位 ${ }_{1} \delta_{i}$ を用いて下式によって算定した ${ }^{4)}$

$$
{ }_{1} \beta_{i} u_{i}=\frac{\sum_{i=1}^{N} m_{i} \cdot{ }_{1} \delta_{i}}{\sum_{i=1}^{N} m_{i} \cdot{ }_{1} \delta_{i}^{2}}, \delta_{i}
$$

図 2 より、柔弱層の位置に拘わらず、いずれのモデルも動的縮約 による等価 1 自由度系の最大応答変形時の応答值（図中のの印）お よびそれ以前の応答履歴においてある時刻までに経験した最大応答 変形点（図中の○印）は、概ね静的縮的による ${ }_{1} S_{a}-{ }_{l} S_{d}$ 曲線上にあ ることがわかる。文献 4)で示された純フレーム建築物の場合と比較 すると、若干精度は劣るものの「等価 1 自由度系における最大応答 時以前の応答履歴では、ある時刻までに経験した最大応答変形が 1 次モードに対する MAP 解析結果とほぼ一致する」という傾向が柔弱 層の位置に拘わらず認められる。なお、純フレーム建築物に比べて 上記の精度が若干低下寸るのは、層崩壊型建築物では 4.3 節で後述 するように「高次モード応答による建築物の塑性化の影響で 1 次モ 一ドのみの塑性化を考慮した場合とは異なる塑性 1 次モードが生じ る」が、MAP 解析においては 1 次モード応答による塑性化の影響の みしか考虑していないためであると考えられる。

一方、最大応答以降の履歴（図中の灰色線）に着目すると、各モ デルとも正負の最大応答点を結んだ等価剛性（図中の一点鎖線）よ りも若干高い等価剛性で定常振動していることが認められる。これ は、層崩壊型建築物では柔弱層の極端な塑性化が等価 1 自由度系の 

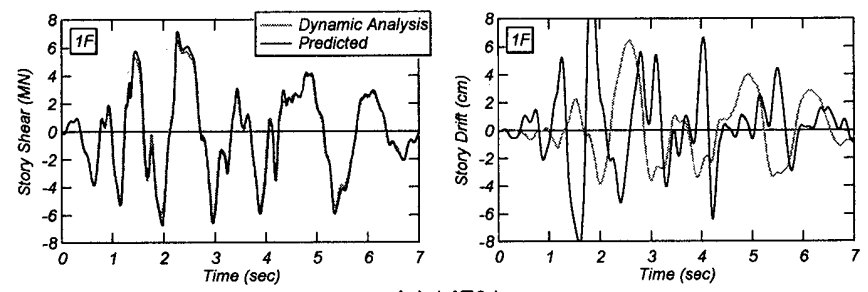

(a) $14 \mathrm{~F} 01$
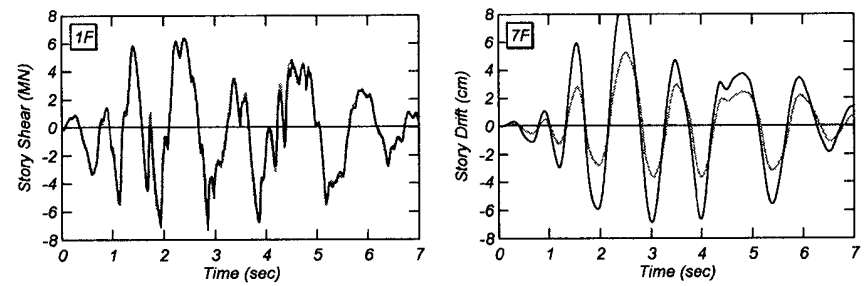

(b) $14 \mathrm{~F} 07$
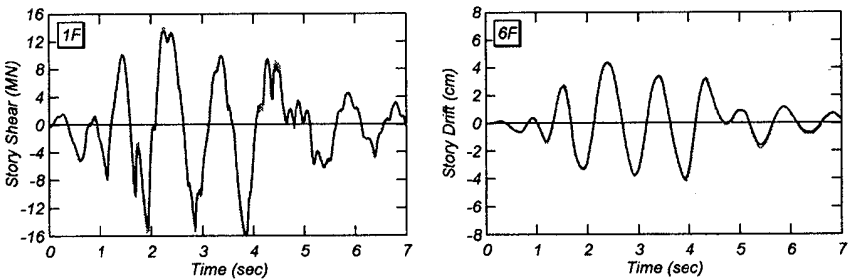

(c) $12 \mathrm{~F} 06$

図 4 式(1)および(2)による層せん断力および層間変形の評価
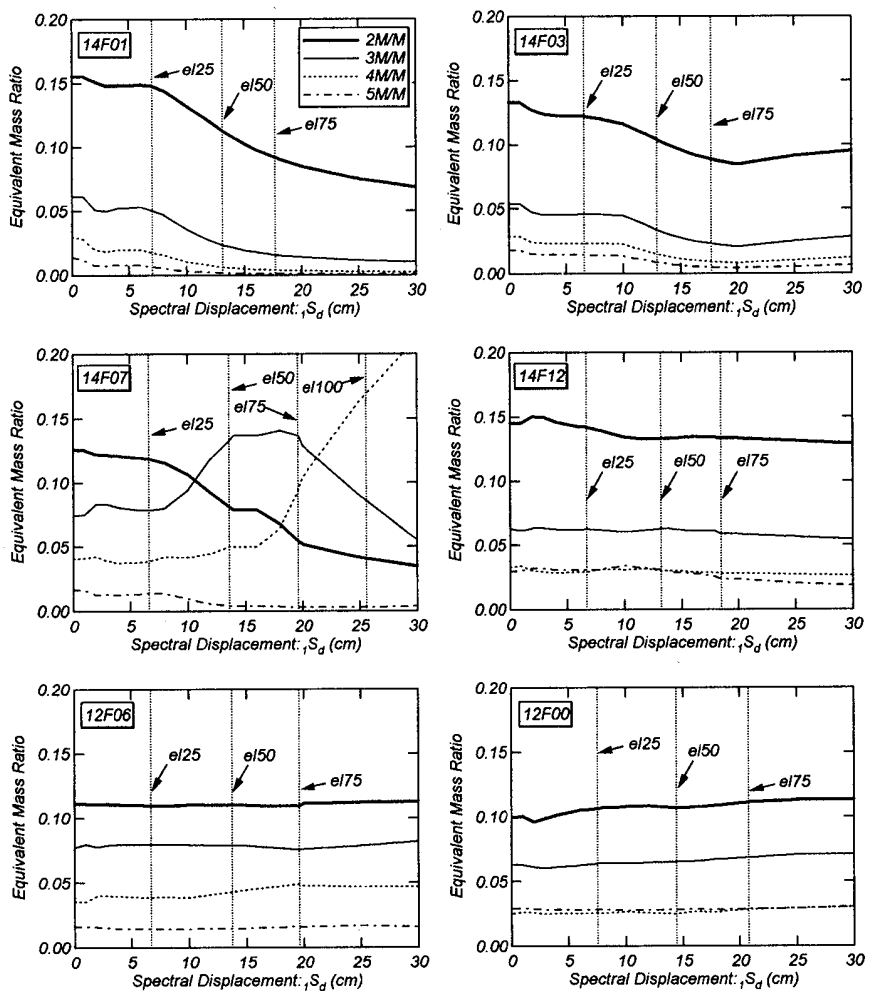

图 5 2 次以上の等価質量比亡 1 次の代表変位の関係

応答特性に影響を及ぼすためと考えられる。具体的には、柔弱層の 塑性化により、等価 1 自由度系の最大応答変形が正負で大きく異な る、いわゆる「応答変形の片寄り」のために正負の最大応答点を結 ぶ等価剛性が低くなると共に、最大忘答時以降、部材に残留変形が 生じた状態（定常振動の中心が原点からずれた状態）で定常振動す るため (図 2 の灰色線)、崩壊層における柱の除荷剛性の影響を受け

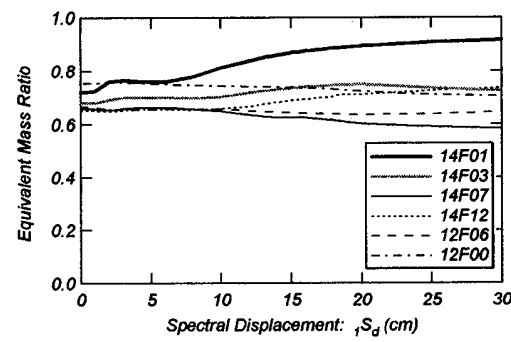

図 61 次等価質量比と 1 次代表変位の関係

て定常振動の剛性が高くなると考えられる。また、12F06 でも応答 変形の片寄りは比較的小さいが、崩壊層（6 層）における柱の除荷 剛性の影響を受けて定常振動の剛性が高くなっていると推測される。 なお、最大応答時以降における定常振動の剛性は、崩壊層が上部に あるほど最大応答時の等価剛性よりも大きくなる傾向が認められる。 これは、崩壊層が上部にあるほど当該層柱の圧縮・引張変形に伴う 回転変形の影響を受ける上層部の未降伏層の数が少なくなり、崩壊 層の柱の履歴性状が等価 1 自由度系の履歴性状により反映され易く なるためと考えられる。

図 3 は El Centro 波 $(75 \mathrm{~cm} / \mathrm{sec})$ 入力時の $14 \mathrm{~F} 01$ における柔弱層（1 層) とその直上の判強層（2層）、および $14 \mathrm{~F} 07$ における柔弱層（7 層）とその直上の剛強層（8層）の層せん断力一層間変形関係を示 している。同図より柔弱層に変形が集中していることおよび片側に 大きな変形を生じていることが認められ、柔弱層の応答特性が図 2 で示した等価 1 自由度系の応答特性を支配していることが見てとれ る。また、図 2 では各モデルとも片側に大きな変形を生じているが、 その傾向は柔弱層が下層にあるほど顕著となっている。これは図 3 において 14F01 の方が 14F07に比べて柔弱層の応答変形の片寄りが 大きいことと対応している。

\section{4. 高次モード応答の評価}

\section{1 既往式 ${ }^{4)}$ による評価}

層崩壊型建築物 5 棟について、文献 4)において多層純フレーム建 築物に対して提案した評価式（式(1)および(2)）を用いて、高次モー ド応答を考虑した層せん断力および層間変形の時刻歴応答を評価し た結果を図 4 に示す。図 4 には El Centro 波 $(75 \mathrm{~cm} / \mathrm{sec}$ ) 入力時の 14F01、 14F07 および 12F06 における高次モード応答を考慮したベースシア と柔弱層における層間変形の時刻歷をそれぞれ示している。また、 図中の灰色線は時刻歷地震応答解析結果を、黒実線は式(1)および(2) による推定結果をそれぞれ表している。

図 4より、ベースシアに関してはいずれのモデルにおいても推定 值と地震応答解析結果が良好な対応関係にあり、式(1)によって層崩 壊型建築物の層せん断力が評価できることが確認された。一方、層 間変形に関しては、14F01において推定值と地震応答解析結果に対 応関係は認められない。また、14F07においても位相はほぼ一致し ているが、推定值が解析結果を過大評価していることがわかる。そ れに対して $12 \mathrm{~F} 06$ においては、推定值と解析結果は良い対応を示し ており、式(2)によって純フレーム建築物に対する場合と同等な精度 で層間変形を評価することができている。以上のことから、層崩壊 型建築物においては、式(1)によって層せん断力を評価することがで きるが、式(2)によって層間変形を評価することができない場合があ ることが明らかとなった。 


\section{2 等価質量比と刺激関数の検討}

式(2)による層間変形の評価ができない原因を明らかにするために、 各モードに対する等価質量と刺激関数に関する検討を行う。図 5 は

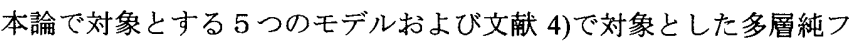
レームモデル (12F00）の静的縮約による 1 次の代表変位, $S_{d}$ の増加 に伴う 2 次モードから 5 次モードまでの等価質量比の変動を示した ものである。図中の el25、el50、el75 および el100 は El Centro 波の $25 \mathrm{~cm} / \mathrm{sec}$ 入力から $100 \mathrm{~cm} / \mathrm{sec}$ 入力までをそれぞれ表している。また、 図 6 は各モデルの 1 次の等価質量比と 1 次の代表変位の関係を比較 したものである。なお、等価質量比は MAP 解析の各ステップにおけ るせん断力ー層間変形関係より 1 次の等価剛性を算定し、その剛性 を用いた固有值解析により求めている。

図 5 より、14F01 では 2 次以上の等価質量比が 1 次の代表変位の 増加に伴って減少する様子が見てとれる。また、14F03 および $14 \mathrm{~F} 12$ でも 14F01 と比較して減少の程度は小さいものの、同様な傾向を示 している。それに対して、中間層に柔弱層を有する 14F07では 2 次
以上の等価質量比が大きく変動している。すなわち、入力レベルが $25 \mathrm{~cm} / \mathrm{sec}$ から $50 \mathrm{~cm} / \mathrm{sec} 、 75 \mathrm{~cm} / \mathrm{sec} 、 100 \mathrm{~cm} / \mathrm{sec}$ と大きくなるにしたが って、2 次以上で最も等価質量比の大きなモードが 2 次から 3 次、 3 次から 4 次一と移り変わっていることがわかる。一方、純フレー 厶の $12 \mathrm{~F} 00$ では 2 次以上の等価質量比の増减はほとんどない。すな わち、純フレーム建築物では塑性化が進行しても各層の変形の 1 次 モード成分が弾性 1 次モードに近い割合で増加するために高次の等 価質量の変動がほとんどないのに対して、層崩壊型建築物では柔弱 層の塑性化が他層に比較して大きいために塑性化以降のI次モード は弾性 1 次モードと異なったものとなり、高次の等価質量の変動が 大きくなると推測できる。なお、壁フレームタイプの $12 \mathrm{~F} 06$ では、 その他の層崩壊型建築物々比べて極端な層崩壊を生じないので、純 フレームの場合と同様に等価質量比の変動が小さい。

また、図 6 より $14 \mathrm{~F} 01$ では 1 次の等価質量比が $10 \%$ 程度増加して いるのに対して、その他のモデルでは 1\%〜3\%程度の増減しか見ら れない。これはピロティ建築物では建築物の塑性化に伴う 1 次のモ
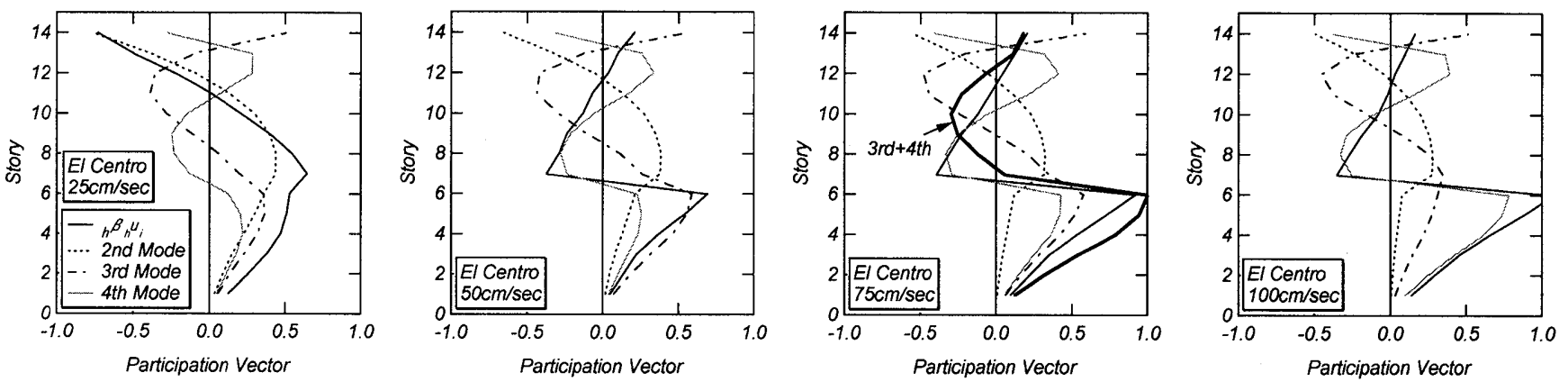

図 7 等価刺激関数の比較（14F07）
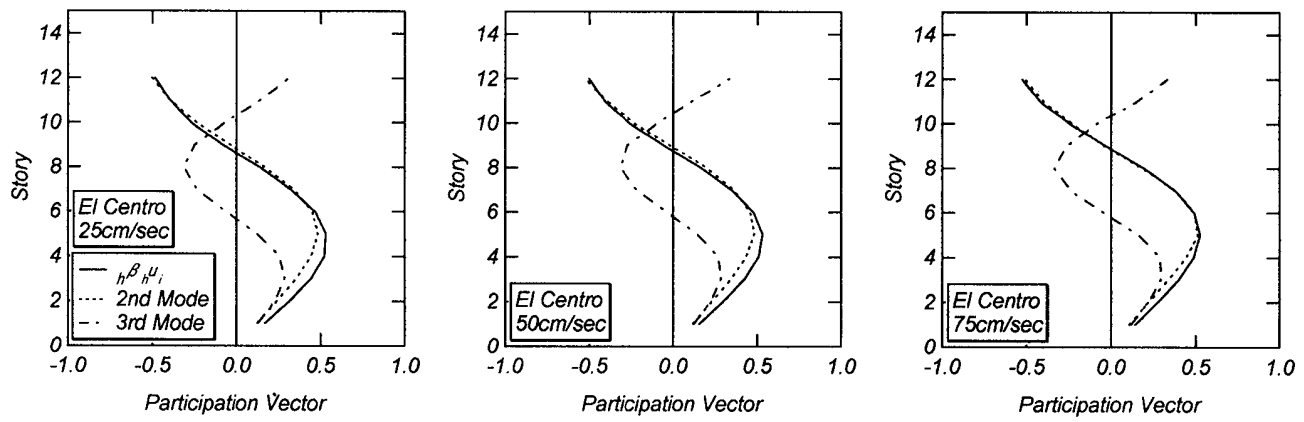

図 8 等価刺激関数の比較 $(12 \mathrm{~F} 00)$

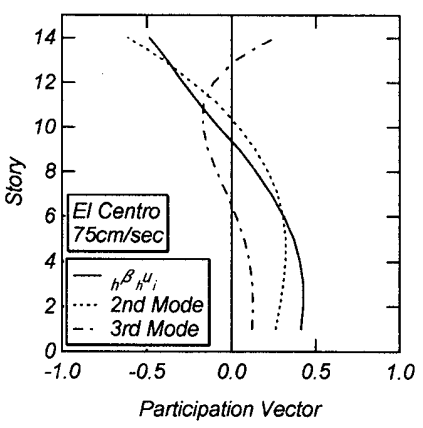

(a) 14F01

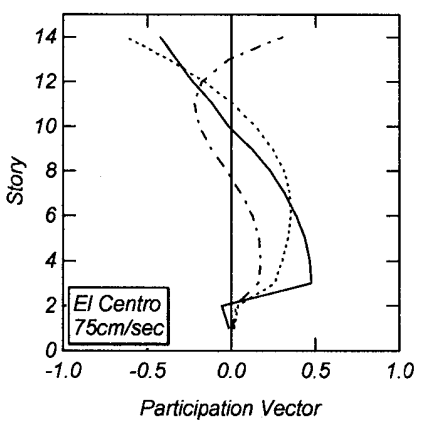

(b) $14 \mathrm{F03}$

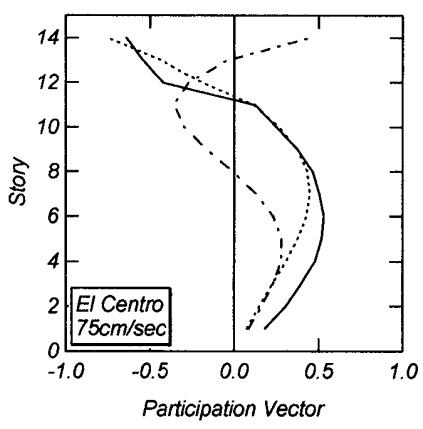

(c) $14 \mathrm{~F} 12$

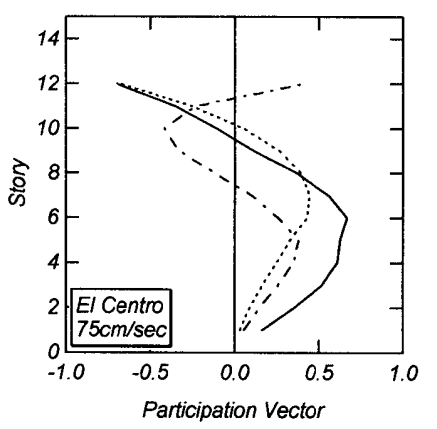

(d) $12 \mathrm{FO} 06$

図 9 各モデルの等価刺激関数（EI Centro 波 $75 \mathrm{~cm} / \mathrm{sec）}$ 
ードの変動が大きいことを意味している。したがって、ピロティ建 築物の応答層閒変形の評価においては塑性化後の 1 次モードを適切 に評価することが特に重要となるといえよう。

図 7 は $14 \mathrm{~F} 07$ の動的縮約による残余等価 1 自由度系の代表変位 ${ }_{h} S_{d}(t)$ が最大值をとる時刻の等価刺激関数 ${ }_{h} \beta \cdot{ }_{h} u_{i}$ (図中の黒実線) と 塑性化を考慮した 1 次モードに対する 2 次、3 次および 4 次の刺激 関数を地震波の入力レベル別に示したものである。塑性化を考虑し た 1 次モードに対する 2 次、 3 次および 4 次の刺激関数は上述した 等価質量比の算定の場合（図 5 ) と同様な固有值解析によって求め ている。同図より、 $25 \mathrm{~cm} / \mathrm{sec}$ 入力では ${ }_{h} \beta \cdot{ }_{h} u_{i}$ は 2 次モードに近い值 を示し、 $50 \mathrm{~cm} / \mathrm{sec}$ 入力および $75 \mathrm{~cm} / \mathrm{sec}$ 入力では 3 次モード、 $100 \mathrm{~cm} / \mathrm{sec}$ 入力では 4 次モードに近い值となっており、それぞれ図 5 において 等価質量比が最も大きいモードと一致していることが認められる。 また、図 5 において $75 \mathrm{~cm} / \mathrm{sec}$ 入力では 4 次の等価質量比の急増が見 られることから 3 次のみならず 4 次の影響も大きいと推測できる。 したがって、図 7 において $75 \mathrm{~cm} / \mathrm{sec}$ 入力では ${ }_{h} \beta{ }_{h} u_{i}$ は 3 次の刺激関 数よりもむしろ図中の太線で示した 3 次 +4 次の刺激関数により近 い值を示している。

一方、図 8 は純フレーム建築物である $12 \mathrm{~F} 00$ の ${ }_{h} S_{d}(t)$ が最大值と なる時刻の等価刺激関数 ${ }_{h} \beta{ }_{h} u_{i}$ と塑性化を考慮した 1 次モードに対 する 2 次および 3 次の刺激関数を地震波の入カレベル別に示したも のである。純フレーム建築物では、入カレベルが大きくなっても各 次のモード形はほとんど変化しておらず、弾性の 1 次モードと塑性 化後の 1 次モードがほぼ同じであることがわかる。

また、図 9 は14F01、14F03、14F12 および 12F06について、El Centro 波 $(75 \mathrm{~cm} / \mathrm{sec})$ 入力時における ${ }_{h} S_{d}(t)$ が最大値となる時刻の等価刺激 関数と塑性化を考慮した 1 次モードに対する 2 次および 3 次の刺激 関数を示したものである。これらのモデルでは 2 次モードの等価質 量が最も大きく、 ${ }_{h} \beta_{h} u_{i}$ は常に 2 次モードに近い值を示している。 また、14F07も含めた全モデルの $75 \mathrm{~cm} / \mathrm{sec}$ 入力時の結果を見ると、 ピロティ建築物である $14 \mathrm{~F} 01$ および上層部に柔弱層を有する $14 \mathrm{~F} 12$ において ${ }_{h} \beta_{h} u_{i}$ と卓越するモードの刺激関数との対応が比較的良い ことが認められる。

以上のことから、式 (2)による層間変形の評価は、等価質量の変動 が小さい、すなわち塑性化に伴うモード変動が小さな建築物に対し ては有効であるといえる。一方、塑性化後のモード変動の大きな層 崩壊型建築物の層間変形の評価に対しては式(2)は適当ではなく、む しろ 2 次以上のモードの中で等価質量比が最大となるモードの刺激 関数を用いて残余等価 1 自由度系の等価刺激関数を評価することが 適切であると考えられる。なお、層せん断力に関しては当該層より 上層に作用する外力の足し合わせであることからモードの影響を受 け難いためモード変動の如何にかかわらず式(1)によって評価するこ とができると推測される。

\section{3 層崩壊型建築物の層せん断力および層間変形の評価式}

既往の純フレーム建築物の層せん断力と層間変形の時刻歷の評価 式 ${ }^{4)}$ (式(1)および式(2)）を、等価質量比が最大となるモードの刺激 関数を用いた評価式に修正すると式(8)および(9)となる。なお、層せ ん断力に関しては式(1)によって評価することができるが、それはモ ードの影響を受け難いためであり、式(9)との整合性を考虑すると式 (8)となる。

$$
\begin{aligned}
& Q_{i}(t)=\sum_{j=i}^{N} m_{j}\left\{{ }_{l} \beta \cdot{ }_{l} u_{j} \cdot{ }_{l} S_{a}(t){ }_{h m} \beta \cdot{ }_{h m} u_{j} \cdot{ }_{h m} S_{a}(t)\right. \\
& \left.-\left(1-{ }_{1} \beta \cdot{ }_{1} u_{j}-{ }_{h m} \beta \cdot{ }_{h m} u_{j}\right) \cdot \ddot{x}_{\theta}(t)\right\} \\
& { }_{s t} \delta_{i}(t)={ }_{l} \beta\left({ }_{1} u_{i}-{ }_{1} u_{i-1}\right), S_{l}(t)+{ }_{h m} \beta\left({ }_{h m} u_{i}-{ }_{h m} u_{i-1}\right)_{h m} S_{d}(t)
\end{aligned}
$$

ここで ${ }_{h m} \beta{ }_{h m} u_{i}$ は塑性化を考虑した 1 次モードに対する 2 次モー ド以上の成分の中で等価質量比が最も大きなものに対する刺激関数 であり、式(10)の関倸がある。

$$
\sum_{i=l}^{N} m_{i} \cdot{ }_{h m} \beta \cdot_{h m} u_{i}=\max \left(\sum_{i=l}^{N} m_{i} \cdot{ }_{h} \beta{ }_{h} u_{i}\right) \quad(h \geq 2)
$$

また、 ${ }_{n m} S_{a}(t)$ および ${ }_{h m} S_{d}(t)$ はそのモードに対応する等価 1 自由度 系の代表せん断力および代表変位を表し、式(11)および(12)で求めら れる。

$$
\begin{aligned}
& { }_{h m} S_{a}(t)=\frac{\sum_{i=1}^{N} P_{i}(t)_{h m} \delta_{i}(t)}{\sum_{i=1}^{N} m_{i} \cdot{ }_{h m} \delta_{i}(t)} \\
& { }_{h m} S_{d}(t)=\frac{\sum_{i=1}^{N} m_{i}{ }{ }_{h m} \beta{ }_{h m} u_{i} \cdot \delta_{i}(t)}{\sum_{i=1}^{N} m_{i} \cdot{ }_{h m} \beta{ }_{h m} u_{i}} \\
& こ こ に 、{ }_{h m} \delta_{i}(t)={ }_{h m} \beta{ }_{h m} u_{i} \cdot{ }_{h m} S_{d}(t)
\end{aligned}
$$

図 10 は式(8)および(9)によって評価した El Centro 波 $(75 \mathrm{~cm} / \mathrm{sec})$ 入力時における $14 \mathrm{~F} 01$ および $14 \mathrm{~F} 07$ の 1 層、7 層および 14 層におけ る層せん断力および層間变形の時刻歷を示している。図中の黒実線 が推定值、灰色線は時刻歴地震応答解析結果を表す。なお、ここで は 4.2 節で述べたように、 $14 \mathrm{~F} 07$ では $75 \mathrm{~cm} / \mathrm{sec}$ 入力時から $100 \mathrm{~cm} / \mathrm{sec}$ にかけて 4 次の等価質量比が急增するため (図 5 )、、 ${ }_{n} \beta \cdot{ }_{h} u_{i}$ は 3 次の 刺激関数よりもむしろ 3 次 +4 次の刺激関数により近い值を示した （図 7 ）ことを考慮して、14F07 の ${ }_{h m} \beta_{h m} u_{i}$ には 3 次 +4 次のモード を採用している。

層せん断力に関しては、14F01 および 14F07 ともに各層とも推定 值と解析結果は良く一致しており、図 4 で示した式(1)による評価と 同程度の精度で評価できている。一方、層間変形に関しては、14F01 については柔弱層の層間変形の評価において図 4 で示した式(2)によ る評価と比較して著しい改善が認められ、その他の層も十分な対応 関係を示している。また、14F07 については柔弱層の層間変形の評 価精度は式(2)によるものに比して向上しているものの、依然として 若干過大評価となっている。

図 11 は図 10 と同様に式(8)および(9)によって評価した El Centro 波 $(75 \mathrm{~cm} / \mathrm{sec})$ 入力時における 14F03、14F12 および $12 \mathrm{~F} 06$ のそれぞ れのベースシアと柔弱層における層間変形の時刻歴を示している。 ベースシアについてはいずれのモデルにおいても推定結果と解析結 果は良く一致していることがわかる。それに対して、層間変形につ いては 14F12 および 12F06 では良く一致するのに対して 14F03 では 過大評価となっている。

層間変形に関して各モデルの評価精度を比較すると、14F01、14F12 および $12 \mathrm{~F} 06$ の精度が比較的良好であり、14F03 および 14F07 の精 度がそれに比して劣る。これは、4.2節で述べたように 14F03および 14F07 では、残余等価 1 自由度系の刺激関数 ${ }_{h} \beta \cdot{ }_{h} u_{i}$ が高次の中で卓 越するモードの刺激関数との対応関係がその他のモデルと比較して 若干劣るためである。 
14F07 では、入力レベルによって 2 次以上のモードの中で最も卓 越するモードが入れ替わる（図 5 ) ことや、 $50 \mathrm{~cm} / \mathrm{sec}$ 入力以降で入 カレベルが大きくなるにしたがって 2 次モードおよび 3 次モードの 影響が小さくなるとともに 4 次モードの影響が大きくなる（図 7 ） ことを勘案すると、高次モード応答による建築物の塑性化が生じて いるものと推測できる。したがって、1 次モード応答による塑性化 によって 1 次等価剛性が低下寸るだけでなく、高次モード応答によ
っても塑性化が生じて建策物全体の剛性が低下するため、岡野ら ${ }^{8)}$ が指摘するように 1 次モード応答のみによる塑性化を考虑した場合 とは異なる塑性 1 次モードが生じるものと考えられる。本解析にお ける評価では、MAP 解析において 1 次モード応答による塑性化の影 響は考慮しているが、上記の高次モード応答による塑性化の影響は 考慮していないため、14F07 のように高次モード応答による塑性化 が生じる場合には、層間変形を評価する適切なモードが得られない。
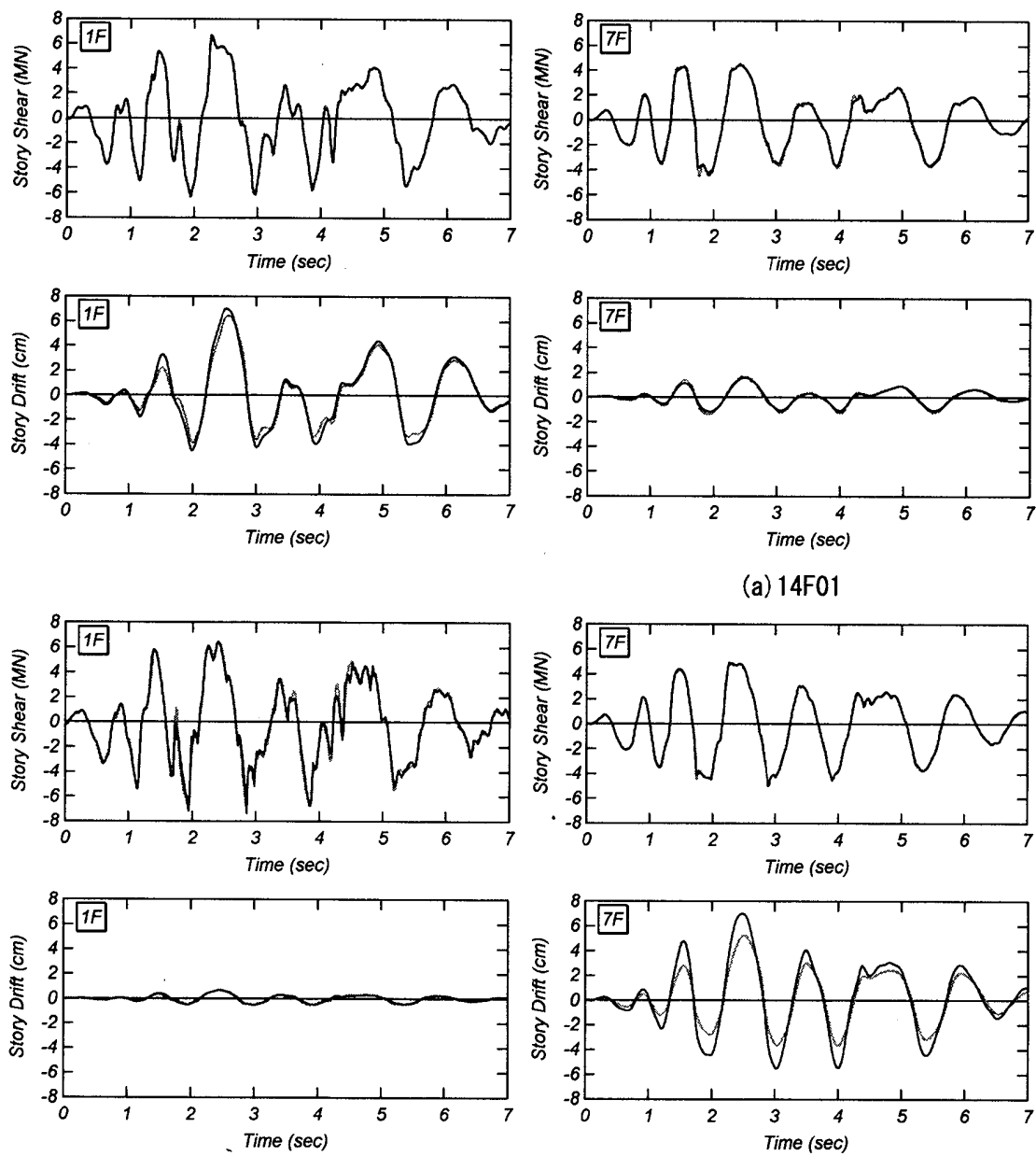

(a) $14 \mathrm{~F} 01$
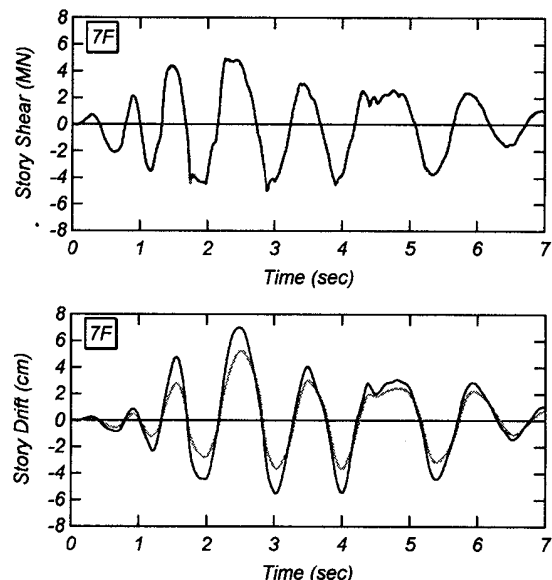

(b) 14F07
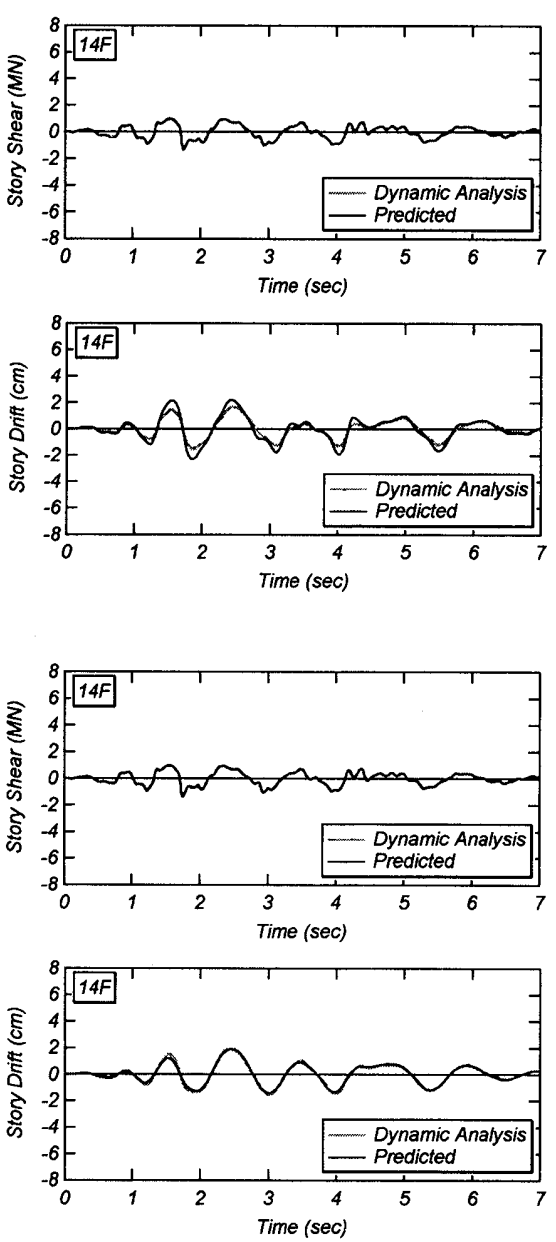

図 10 式 (8)および(9)による層せん断カおよび層間変形の時刻歴の評価（14F01 および 14F07 EI Centro 波 75cm/sec）
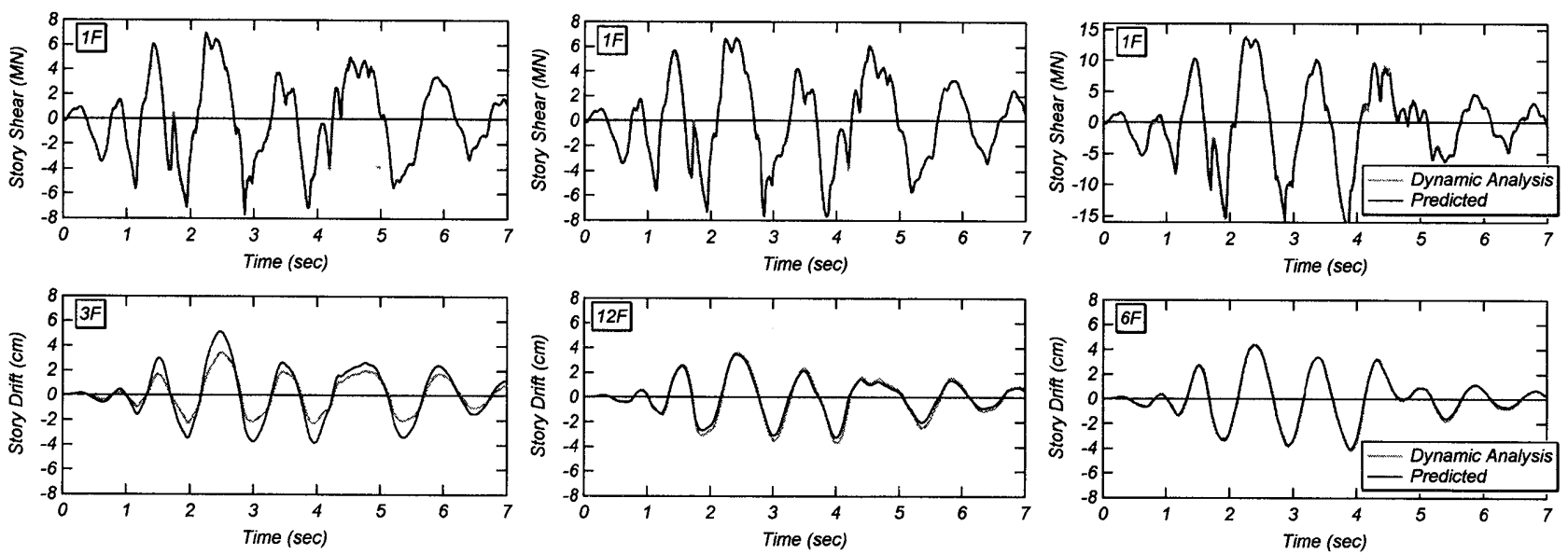

(b) $14 \mathrm{~F} 12$

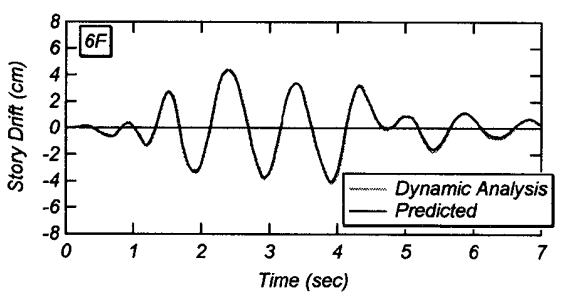

(c) $12 \mathrm{FO} 06$

図 11 式(8)および(9)による層せん断カおよび層間変形の時刻歴の評価（14F03、14F12 および $12 \mathrm{~F} 06$ El Centro 波 $75 \mathrm{~cm} / \mathrm{sec}$ ) 
一方、14F03 では、地震応答解析において応答変形の高次モード成 分が柔弱層（ 3 層）と柔弱層直下の層（2 層）で逆位相となってい るために、図 9 において 2 層および 3 層での等価刺激関数および 2 次の刺激関数の分布に顕著な違いが現れている。しかしながら、本 解析で用いた極端なケースにおいても式(9)による予測精度は比較的 良好であるといえ、本論で提案した方法によって層崩壊型建築物の 層間変形を概ね評価できるものと考えられる。

\section{5.まとめ}

限界耐力計算による層崩壊型建築物の地震応答評価に高次モード の影響を考慮することを目的として、 1 層、 3 層、 7 層、12 層に柔 弱層を有する 14 層の層崩壊型建築物および 6 層に柔弱層を有する 12 層の壁フレーム建築物を対象とした MAP 解析および時刻歷地震 応答解析を行った。さらに、既往の提案式（式(1)および(2)）を用い て層崩壊型建築物の層せん断力および層間変形の時刻歴応答の評価 を試み、それらの適用性を検討した。

本研究で得た知見を以下に要約する。

(1) 層崩壊型建築物では純フレーム建築物と異なり 1 次モードのみ ならず、高次モードにおいても塑性化に伴うモード変動が大きい。 ただし、極端な層崩壊を生じない場合（12F06）には、塑性化に 伴うモード変動が比較的小さい傾向にある。

(2) 層せん断力はモード変動の影響を受け難いため、立面的に整形な 多層建築物に対する層せん断力の時刻歷応答評価式である式(1) は、層崩壊型建築物にも適用できる。

(3) 立面的に整形な多層建築物に対する層間変形の時刻歷応答評価 式である式(2)は、塑性化に伴う各固有モードの変動が小さい場 合に適用できる。これは、式(2)の適用対象が全体崩壊形からあ まり逸脱しない崩壊形となる建築物であることを意味する。

(4) 層崩壊型建築物では、2 次モード以上の高次モードの中で等価質 量比が最大となるモードの刺激関数を用いて残余等価 1 自由度 系の等価刺激関数を評価することが妥当である。

(5) 層崩壊型建築物の層間変形の時刻歴応答は高次モードの変動も 考慮した式(9)により概妏評価できる。ただし、塑性化の進行に 伴って高次モードの等価質量比の変動が大きく、卓越するモード
が入れ替わるような場合には、評価精度が低下する傾向にある。

(6) 層崩壊型建築物の場合でも等価質量比の変動が小さい場合 （12F06）には、層閒変形の時刻歷応答の評価精度は、式(2)およ び式(9)でほぼ同等となる。

(7) ピロティ建築物では塑性化が進むにつれて 1 次の等価質量が増 大し、大きなモードの変動が生じるため、1 次のモードを適切に 評価することが特に重要となる。

\section{参考文献}

1) 国土交通省住宅局建築指導課、他 3 団体共編：2001 年版 建築物の構造関 係技術基準解説書、工学図書、586pp、2001.3

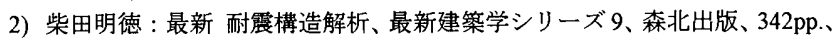
1981.6

3) 倉本洋 : 限界耐力計算における地震応答評価法の問題点とその改善、振動 運営委員会シンポジウム論文集「建築物の終局耐震性能評価手法の現状と 課題 一限界耐力計算・エネルギー法・時刻歴解析法の比較一」、日本建筑 学会、pp.48-99、2005.5

4) 倉本洋 : 多層建築物における等価 1 自由度系の地震応答特性と高次モード 忘答の予測、日本建築学会構造系論文集、第 580 号、pp.61-68、2004.6

5) 倉本洋 : 限界耐力計算による多層建築物の最大地震応答評価における高次 モード応答の考慮、日本建築学会構造系論文集、第 587 号、pp.69-76、2005.1

6) 倉本洋、中坂亮、松本和行：限界耐力計算による多層制震建築物の地震応 答評価、日本建築学会構造系論文集、第 593 号、pp.51-58、2005.7

7) 倉本洋、秋田知芳 : 多層壁フレーム建筑物の等価 1 自由度系縮約と高次モ 一ド忘答せん断力の評価、日本建築学会構造系論文集、第 605 号、pp.79-86、 2006.7

8）岡野創、小鹿紀英、吉川和秀：高次モード忘答を考慮した等価線形化法に よるせん断型モデルの忘答評価、日本建築学会構造系論文集、第 591 号、 pp.113-121、2005.5

9) 小林正人、井澤保一、洪忠熹 : モード連成作用を考慮した中間層兔震構造 の各部地震応答予測、日本建築学会構造系論文集、第 572 号、pp.73-80、 2003.10

10) 山下忠道、向井洋一、井上豊 : 中間層に免震装置を設置した建物における 免震層の上部一下部構造の応答の連成と制御に関する研究、日本建筑学会 構造系論文集、第 591 号、pp.35-42、2005.5

11) Kuramoto H. and Matsumoto K.Mode-Adaptive Pushover Analysis for Multi-Story RC Buildings, Proceedings of Thirteenth World Conference on Earthquake Engineering, Vancouver, Canada, Paper No.2500 (CD-ROM), 2004.8

12) Gu J.H., Inoue N. and Shibata M.: Inelastic Analysis of RC Member Subjected to Seismic Loads by Using MS Model, Journal of Structural Engineering, AIJ, Vol.44B, pp.157-166, 1998.3

13）倉本洋、栜使川原正臣、小鹿紀英、五十田博 : 多層建築物の等価 1 自由度 系縮約法と地震応答予測精度、日本建築学会構造系論文集、第 546 号、 pp.79-85、2001.8 